\title{
Modern slavery challenges to supply chain management
}

\author{
by Stefan Gold, Alexander Trautrims, Zoe Trodd
}

This is a non-final and non-copy-edited version of the article published in "Supply Chain Management: An International Journal":

Gold S, Trautrims A, Trodd Z. (2015) Modern slavery challenges to supply chain management. Supply Chain Management: An International Journal, 20(5): 485-494.

(DOI: 10.1108/SCM-02-2015-0046)

For citations please refer to the final article (http://www.emeraldinsight.com/doi/full/10.1108/SCM-02-2015-0046). 


\section{Abstract}

Purpose

Although many international supply chains are (most often unknowingly) connected to slave labour activities, supply chain managers and research have so far neglected the issue. This will most likely change soon as civil society lobbying and new legislation imposes increasing litigation and reputational risks on companies operating international supply chains.

\section{Design/methodology/approach}

The paper provides a definition of slavery, explores potentials for knowledge exchange with other disciplines, discusses management tools for detecting slavery as well as suitable company responses after its detection, and outlines avenues for future research.

\section{Findings}

Due to a lack of effective indicators, new tools and indicator systems need to be developed that consider the specific social, cultural and geographical context of supply regions. After detection of slavery, multi-stakeholder-partnerships, community-centred approaches, and supplier development appear to be effective responses.

\section{Research limitations/implications}

New theory development in supply chain management is urgently needed to facilitate the understanding, avoidance and elimination of slavery in supply chains. As a starting point for future research, we conceptualize the challenges of slavery to supply chain management, focussing on capabilities and specific institutional context.

\section{Practical implications}

The paper provides a starting point for the development of practices and tools for identifying and removing slave labour from supply chains.

\section{Originality/value}

Although representing a substantial threat to current supply chain models, slavery has so far not been addressed in supply chain management research.

\section{Keywords}

Slavery, supply chain compliance, supply chain collaboration, human rights, labour rights, supply chain auditing.

\section{Article classification}

Viewpoint 


\section{Introduction}

In 2014, the Global Slavery Index (GSI) counted 35.8 million slaves worldwide. Although slavery is officially outlawed everywhere, this estimate is the highest absolute number of slaves in the history of mankind. The most affected countries are India, China, Pakistan, Uzbekistan, Russia, Nigeria, the Democratic Republic of the Congo, Indonesia, Bangladesh and Thailand (GSI, 2014), though slavery is by no means limited to Africa and Asia: the GSI estimates over half a million slaves within the European Union (GSI, 2014). ${ }^{1}$

Although much of the public debate on modern slavery circles around the topics of trafficking and sexual exploitation, the majority of slaves are in forced labour: $78 \%$, according to the International Labour Organization (ILO) (including the $10 \%$ of slaves who are in stateimposed enslavement), while only $22 \%$ are in forced sexual exploitation (ILO, 2012a). Most slaves are used in simple, non-technological, traditional work: agriculture, brick-making, mining and quarrying, textile manufacture, leather working, gem-working and jewellerymaking, cloth and carpet-making, domestic service, forest clearing, and charcoal making (Bales and Trodd, 2013). As well, the focus on trafficking ignores the majority of slaves who were enslaved without being trafficked. By recent ILO numbers, only $29 \%$ of slaves crossed borders. Another $15 \%$ were moved within their countries and $56 \%$ were not moved at all (ILO, 2012a).

By shifting our focus from sex trafficking to labour slavery, we are able to shift our attention to supply chains. Slavery taints numerous of our raw materials, commodities and goods. International supply chains driven by the principle of comparative cost advantages find their way to this slave labour (and might even be seen as nourishing it) (cf. Lund-Thomsen and Lindgreen, 2014). Supply chains leverage the profitable exploitation of cheap human resources-facilitated by global inequality and hierarchical social relations (LeBaron, 2013) - for the production of goods to be sold on the world market. While this constant striving to reduce costs is inherent to many supply chains, in the case of slave labour, slaveholders retain the bulk of the profits, which never reach actors further down the supply chain since the origin of slave-made commodities is concealed (Datta and Bales, 2013). Slavemade commodities are inseparably mixed up with commodities of other provenance at the next supply chain tier down towards the consumer, for example at the exporter or wholesaler level. Slave labour therefore appears to be largely hidden from focal companies predominantly placed in the big consumer markets of the industrialised world.

However, non-governmental organisations (NGOs) might blame focal companies for deliberately not trying hard enough to detect those exploitative practices (Wolf, 2014). As supply chains are internationally connected and highly outsourced today, the risk of using slave labour somewhere in the supply chain is present in almost all industries, from electronics, high-tech, automotive and steel to agriculture, seafood, mining, garment and textiles (David et al., 2012). One illustrative real-world example of how slavery affects global supply chains and threatens the brand reputation of focal companies is the case of

\footnotetext{
${ }^{1}$ The 2014 figure represented an update to the 2013 GSI count of approximately 30 million slaves, a figure also quoted in an EU Parliament (2013) briefing paper. Today's slavery is notoriously difficult to quantify because it is a hidden crime. The GSI is the first attempt to measure slavery in today's world, country by country, and its researchers make all quantitative data freely available for re-analysis, also acknowledging that they continue to refine the methodologies for the annual index. The researchers use nationally representative, random-sample surveys, alongside data from other pre-existing surveys and a review of secondary sources, plus an extrapolation method. A detailed methodology paper for the GSI is available at www.globalslaveryindex.org/methodology.
} 
European and US supermarkets (including Carrefour, Tesco, Walmart) selling prawns produced with slave labour. In 2014, the Thai supplier Charoen Pokphand Foods was accused of utilizing fishmeal stemming from fishing boats operated with slaves on their prawn farms (Hodal et al., 2014). Public pressure forced the supermarkets to remove this supplier's prawn products from their shelves.

In recent years, legislators have started to address this issue. As early as 2005 , the Brazilian government launched a voluntary multi-stakeholder initiative called the National Pact for the Eradication of Slave Labour (2005) in collaboration with the ILO. It engages signatory companies in attempts to eradicate slave labour from their supply chains: they must cut ties with businesses that make use of slavery, incorporate contractual clauses associated with practices that characterize slavery and implement mechanisms to track products. The Pact's committee also offers free training on slavery to employees of signatory companies and their suppliers. More than 400 companies have joined so far, with supply chain studies undertaken every three years at the government's request by the ILO, NGOs and trade unions. Brazil's Ministry of Labour also publishes a "dirty list" (Lisa Suja do Trabalho Escravo) that it updates every six months, listing the names of individuals and corporations deemed responsible for situations of slavery, subjecting them to sanctions (such as preventing them from accessing public funds). The list goes to public service agencies and banks so that they can deny finance, grants and public credit to those listed. New legislation is also holding companies accountable in the United States. Since 2012, the California Transparency in Supply Chains Act requires big companies who are doing business in California to report on their efforts to abolish slavery and human trafficking in their supply chains. ${ }^{2}$ In the UK, a Modern Slavery Bill became law in March 2015, requiring companies to prepare and make publically available a statement every financial year that explains the steps taken to ensure that slavery is not taking place in any of its supply chains. ${ }^{3}$ And at the level of international law, in June 2014 the ILO revised its Convention on Forced or Compulsory Labour in order to address the still existing implementation gaps (Pollitt, 2014).

Therefore the use of slave labour (including by beyond-first-tier-suppliers) becomes a considerable legal risk for focal companies. The avoidance of expensive and reputationdamaging litigation might be seen as a crucial task, similar to the obligation to report on conflict metals including tin, tantalum, tungsten and gold by the Dodd-Frank financial reforms act in the United States. Although there is no fine for having conflict minerals in the supply chain, the act is a de facto ban on those materials, at least for companies susceptible to naming-and-shaming (Bosco and Munck, 2013). Industry has responded through initiatives like the Conflict Free Smelter Program (CFSP), which uses third-party audits at smelters and refineries since 2010 in order to ensure conflict-free provenance of minerals supplied to the world market (Bafilemba et al., 2014). Following the traditional managerial paradigm of profit maximisation, the investments in ensuring a slavery-free supply chain trade off against the risks of litigation and reputation damage. From this point of view, government regulation and

\footnotetext{
${ }^{2}$ For another example of U.S. government attempts to address slavery in supply chains, see the U.S. Department of Labor's (2014a, 2014b) list of goods and products made with child and forced labour. See also the UN's Guiding Principles on Business and Human Rights (United Nations, 2011). Although it requires legislation at state or EU level to determine what businesses must do, the UN explains in its guidelines what businesses should do.

${ }^{3}$ See also the failed attempt in 2012 to pass the Transparency in UK Company Supply Chains (Eradication of Slavery) Bill, available at: http://www.publications.parliament.uk/pa/bills/cbill/2012-2013/0026/13026.pdf (accessed 31 January 2015).
} 
risk minimisation drive supply chain management (SCM) (Magnan et al., 2011; CIPS-Walk Free, 2013). But a distinctive strategy of marketing sustainable products for a premium price may also incentivise companies to ensure that their supply chains are slavery-free (Seuring and Müller, 2008).

Against this background, we ask the following questions relevant for academic research and supply chain practice: (1) how should we define slavery today? Avoiding slave labour in supply chains requires knowing what the term entails and how it is legally defined. Then, recognising that we can only approach the problem of slavery in our supply chains if we really understand the phenomenon, including insights from other disciplines that have been researching slavery from various angles over the past 15 years, we ask: (2) what can supply chain research learn from other disciplines about slavery in supply chains? Subsequently, we turn to the issue of how to improve the current situation by taking suitable actions concerning SCM: (3) which management tools and indicator systems might be suitable for detecting slavery within international supply chains? And (4) what is a suitable response by a focal company when it detects slavery at any point in its upstream supply chain? We provide insights through current best-practice examples of detecting and responding to slavery in supply chains. Finally, we conclude by asking: (5) which avenues for future research would facilitate a better understanding of the problem and support supply chain managers in formulating an adequate response? The remainder of the paper is structured around these research questions.

\section{(1) Defining slavery}

The definition of slavery has been controversial since the early days of the modern antislavery movement in the 1990s but we recommend the definition put forward in the BellagioHarvard Guidelines on the Legal Parameters of Slavery, written by the Members of the Research Network on the Legal Parameters of Slavery in 2012. The Guidelines use the legal definition of slavery found in the 1926 Slavery Convention, which defines slavery in international law as "the status or condition of a person over whom any or all of the powers attaching to the right of ownership are exercised" (Bellagio-Harvard Guidelines, 2012, p.1). As slavery is banned in every country of the world, slave-holders can no longer rely on law to enforce ownership. Instead, the Guidelines explain, they exercise the powers attaching to the right of ownership through possession: "control over a person by another such as a person might control a thing". Therefore, "slavery" in its contemporary form, as a by-product of our global production system, may be defined as controlling a person "in such a way as to significantly deprive that person of his or her individual liberty, with the intent of exploitation through the use, management, purchase, sale, profit, transfer or disposal of that person" (Bellagio-Harvard Guidelines, 2012, p.2). This definition captures the reality of slavery: slaves are under violent control and are paid nothing beyond subsistence. They have lost free will and free movement, are economically exploited, and no longer have control over the nature, environment and conditions of their work. Building on this definition, we define slavery in supply chains as the exploitation of a person who is deprived of individual liberty anywhere along the supply chain, from raw material extraction to the final customer, for the purpose of service provision or production. 
Slavery mainly takes three forms today: (1) Chattel slavery, in which people are born, captured or sold into permanent slavery; (2) debt bondage slavery, in which people pledge themselves against loans for an undefined length of time, but their labour does not diminish the debt due to extortionate interest rates or false accounting, and; (3) contract slavery where fake employment contracts lure workers into the trafficking and enslavement process (Bales and Trodd, 2013). Debt bondage slavery and contract slavery can be hard for supply chain managers to spot even if audits are carried out, as slave-holders use commonlyoccurring business mechanisms (e.g., loans and contracts) to hide the enslavement.

As global supply chains are operating under multiple legal and cultural value systems (LundThomsen and Lindgreen, 2014), slavery can appear in various forms in a supply chain, which makes its identification more challenging and also requires an understanding of local contexts. Centralised supply chain monitoring from an organisation's headquartersalthough useful for many supply chain processes like quality control and tracking deliveries-is prone to struggle with slavery identification. Within contract slavery, in particular, it is more difficult to determine a clear division between free and unfree labour. Contract slavery -in contrast to chattel slavery-involves an exchange of money that induces workers to journey to their new place of work. But when mechanisms are in place to stop them from withdrawing their work-they cannot leave, they are not paid and their passports or legal documents have been taken-they are in an unfree labour situation.

\section{(2) What can supply chain research learn from other disciplines about slavery in supply chains?}

Despite being new to the supply chain agenda, slavery has been a research topic in many other areas of social sciences and humanities, including law, sociology, geography, politics, literature, visual culture, international development, and history (e.g., Allain, 2007; Bales et al., 2009; Breman, 2007; Barrientos et al., 2013). To explore how to detect and remove slave labour from supply chains, SCM research can build on the knowledge from these disciplines. For example, knowledge from the fields of history and area studies is crucial for identifying instances of slave labour. Slave-traders use local beliefs and traditions to gain control over individuals-as in Niger, Mauritania, Ghana, Thailand, Nigeria, and China, where differences of race, ethnicity and religion still form the dividing lines between slave and free. India still has an internal Hindu "caste" system. The segregated people of the lowest caste, the "dalit," are denied access to work, education and land, and form a large proportion of the country's slaves. Or in Saudi Arabia and Kuwait, Muslim Arabs enslave the minority Nigerian Muslims, Filipino Christians and Sri Lankan Hindus. In fact, around the world, individuals who belong to marginalized groups - whether indigenous peoples, tribal groups, refugees, or migrantsare targeted for trafficking and enslavement (Bales et al., 2009).

In another example, the interdisciplinary field of environmental studies-encompassing geography, law, economics, politics and sociology—might help to underpin a risk-based approach in monitoring supply chains for slavery. Slavery thrives amid the chaos of natural disaster and environmental destruction, and slavery in turn fuels a destruction of the natural environment. In the Indian state of Uttar Pradesh, thousands of slaves working in stone quarries destroy the environment. They are forced to cut down forests for the minerals underneath, and mining erodes any remaining soil. Even if the slaves escape, the 
devastated natural environment offers no way to make a living. Within this cycle, they are then more vulnerable to slave-traders, who in turn press slaves to wreck the environment still further. Around the world, forests, reefs, coastal environments and protected areas are destroyed by slave labour (Bales et al., 2009; Bales, 2016).

Knowledge from these diverse disciplines has the potential to inform developmental approaches to eliminating slavery from the local labour market and local suppliers. It is also essential for the training of sourcing specialists and the development of procurement procedures. In addition, the legal definition of slavery, the evidence requirements for slavery litigation and the strictness of liability are within the remit of policy-making and interpretation in legal practice, but will have an impact on supply chain auditing and supplier selection: the required levels of supply chain monitoring, and the extent to which responsibility might increase with a company's size, resources, and brand visibility. Table 1 outlines the potential relevance of other research disciplines to SCM research and practice.

Table 1: Connecting research on slavery from other disciplines to SCM research and practice

\begin{tabular}{|c|c|c|}
\hline Discipline & Relevant research & Link to SCM \\
\hline Finance / Accounting & Auditing systems & $\begin{array}{l}\text { Monitoring suppliers; compliance } \\
\text { systems }\end{array}$ \\
\hline Law & $\begin{array}{l}\text { Legal definitions of slavery; } \\
\text { prosecution of slave-holders }\end{array}$ & $\begin{array}{l}\text { Legal evidence for slavery; litigation } \\
\text { risk }\end{array}$ \\
\hline Development studies & $\begin{array}{l}\text { Causes and reduction of } \\
\text { poverty }\end{array}$ & $\begin{array}{l}\text { Indicators for slavery in a } \\
\text { geographical region }\end{array}$ \\
\hline $\begin{array}{l}\text { Area studies / } \\
\text { Sociology }\end{array}$ & $\begin{array}{l}\text { Race / ethnicity / religion / } \\
\text { caste as factors in } \\
\text { enslavement }\end{array}$ & $\begin{array}{l}\text { Indicators for slavery in a } \\
\text { geographical region }\end{array}$ \\
\hline Environmental studies & $\begin{array}{l}\text { Environmental destruction } \\
\text { as a factor in enslavement }\end{array}$ & $\begin{array}{l}\text { Indicators for slavery in a } \\
\text { geographical region }\end{array}$ \\
\hline Political science & $\begin{array}{l}\text { Evolution of political and } \\
\text { judicial systems }\end{array}$ & $\begin{array}{l}\text { Collaboration with local justice } \\
\text { systems }\end{array}$ \\
\hline Foreign policy & International sanctions & $\begin{array}{l}\text { Disruption risk from sanctions } \\
\text { against countries that form part of } \\
\text { global supply chain network }\end{array}$ \\
\hline Economics & $\begin{array}{l}\text { Economics of contemporary } \\
\text { slave trade / slavery }\end{array}$ & $\begin{array}{l}\text { Indicators for slavery in a } \\
\text { geographical region }\end{array}$ \\
\hline History & $\begin{array}{l}\text { Historic slave trade and its } \\
\text { elimination }\end{array}$ & $\begin{array}{l}\text { Approaches to eradicating slavery } \\
\text { from supply chains, interrupting the } \\
\text { supply of slaves, past campaigns } \\
\text { for morally informed consumption } \\
\text { and product boycotts }\end{array}$ \\
\hline
\end{tabular}




\section{(3) Management tools and indicator systems for mitigating slavery in supply chains}

SCM can use existing research from these other disciplines into the specific social, cultural and geographical contexts of slavery-i.e. the broader institutional setting (Crane, 2013)-to develop new indicators for slave labour in SCM practice and tools for making supply chains slavery-free. These indicators are currently absent or inadequate. A good starting-point, however, is sustainable SCM practices, which comprise a comprehensive conceptualisation of supply chain actors that extends to multi-stakeholder networks by the inclusion of, for example, NGOs, governmental and international organisations (Pagell and Wu, 2009). Furthermore, focal firms may increase suppliers' social and environmental performance through supplier development (Hall and Matos, 2010; Gimenez and Tachizawa, 2012) and "decommoditization" (Pagell et al., 2010) of suppliers by granting privileged conditions and long-term relationships (Andersen and Skjoett-Larsen, 2009). Making the supply chain more transparent and traceable is crucial for many supply chains such as food or textile but difficult to achieve (Wieland and Handfield, 2013). So focal firms engage in supplier monitoring driven by the objective of minimising risks from materials, products, and operations (Seuring and Müller, 2008). The exchange of information may eventually lead to collaboration and increased supply chain performance in the economic, social and environmental dimensions of sustainability. Third party standards and certification schemes may facilitate transparency of business activities and traceability of materials and products down the supply chain and have been widely used for ensuring sustainability (Müller et al., 2009). Finally, supplier sustainability assessment and reward systems may financially incentivise suppliers complying with minimum standards or suppliers continuously increasing their sustainability performance (Stiller and Gold, 2014).

Features of these practices may be categorised in the compliance-based paradigm of sustainable SCM which focusses on monitoring and control by focal companies, and the collaboration-based paradigm which aims to establish multi-stakeholder networks of actors who are controlling each other and leveraging complementary capabilities for the overall benefit of the supply chain. While the shortcomings of both paradigms have been exposed in detail by Lund-Thomsen and Lindgreen (2013), we stress in this paper that focal companies' severe problems with tackling slave labour derive partly from the incongruence of the accountability they are ascribed by society, and the responsibility they are assuming themselves with their actual reach of power. This power diminishes rapidly beyond their direct suppliers (Grimm et al., 2014; Tachizawa and Wong, 2014). However, what is even more important is the fact that practices of sustainable SCM in general have little effect when dealing with illegal activities that are actively hidden (cf. the phenomenon of audit fraud by the audited company; Lund-Thomsen, 2008). For instance, slave-holders skimming huge profits from their activities will not be susceptible to change in response to premium-price incentives for social standards from the buying company. They might instead take the premium and the same time extend their existing profitable business model.

Due to the strong incentives of slave-holders to actively hide the nature of their business, existing indicators of financial and operational (Gunasekaran et al., 2004) as well as sustainable supply chain performance (Bai and Sarkis, 2014; Varsai et al., 2014) are not easily adaptable for the detection of slavery in fragmented multi-tier supply chains. The widely-used reporting guidelines by the Global Reporting Initiative (GRI) address briefly the aspect of "forced or compulsory labor" as "operations and suppliers identified as having significant risk for incidents of forced or compulsory labor, and measures to contribute to the 
elimination of all forms of forced or compulsory labor" (GRI, 2013, p.73). It is noticeable that GRI (2013) avoids the terms "slave" and "slavery" throughout its whole report and prefers to use "forced and compulsory labor". Furthermore, it does not give guidance on the crucial question of how to assess the risk for incidents of slavery.

The first step to developing suitable indicators is the enhancement of supply chain visibility and transparency by supply chain mapping, even though it is not clear how to detect slave labour activities in parts of the supply chain that deliberately do not want to be detected. As a rule of thumb, the following conditions may serve as rough initial indicators for the existence of slave labour (CIPS-Walk Free, 2013). It is advisable that supply chain managers, auditing teams, and certification bodies take an especially careful approach if one or more of these conditions apply:

- Low worker protection due to inadequate laws, enforcement, and government accountability

- High percentage of working poor

- Lack of other employment opportunities and domination of labour market by one or a few employers

- Agent-based recruitment of labourers

- Social acceptance of worker exploitation

- Widespread discrimination against certain groups of workers

- High percentage of migrants or minorities in the workforce

- Location of production activities in conflict zones

- High proportion of low skilled labour in industries such as raw material extracting and/or processing industries

While such indicators may serve as a general early warning system for the risk of slavery occurrence, it is clear that in practice different lenses are required to actually detect slave labour in supply chains. This search may for example involve the analysis of economic data on various levels (village, region, etc.) or the assessment of photos taken by satellites and planes. The absence of economic activity in a region that would otherwise be generated by the workforce spending their wages or an unsustainable way of living in rural settlements are warning signs for slave labour conditions. The verification of such indicators clearly requires an approach that goes beyond the traditional tick-box approach of supply chain auditing (Lund-Thomsen, 2008; Wieland and Handfield, 2013).

Useful methods to identify slave labour will vary depending on the context of the investigation. For example slavery was found in numerous cases on sugar cane plantations that produce ethanol fuel in Brazil (Rush, 2007). In the Brazilian ethanol industry occurrences of slavery were overrepresented in geographical areas where only few producers could be found as these plantations dominated the local market for agricultural work. Slave labour was also found mainly in geographical areas of recent expansion and was more common when labourers were employed indirectly through agents and not by the ethanol producers directly (McGrath, 2013). The proliferating occurrence of such industry characteristics and employment structures must be taken as indicators for a higher risk of slavery occurrence and increase suspicion, although each on their own cannot be considered sufficient evidence. Understanding the characteristics of such cases provides indicators for the investigation of suppliers. 
The existence of a functioning state administration was fundamental in this approach. In the Brazilian ethanol industry, state labour inspectors identified slave labour through observation and independently-conducted interviews. Evidence for slave labour came from the presence of numerous indicators such as degrading working conditions, the absence of health and safety considerations, and non-transparent pay systems but could also be seen through indirect measures such as the workforce demographics (where white workers were strongly underrepresented) (McGrath, 2013). The approach in this case relied on a functioning state labour inspection capacity. Where this is not in place, multi-national companies are essentially asked to step into the gap by policing their supply chains (Vermeulen and Kok, 2012). Large businesses with more specialised functions and more resources may find it easier to develop capacity for such activities, but this may be more difficult for small- and medium-sized enterprises operating in fragmented industries.

Another example for the identification of forced labour was found in Indonesian anchovy fishing. Here slavery was identified through a survey and qualitative interviews. Independent researchers surveyed and interviewed workers using the ILO's catalogue for slave labour indicators (ILO, 2012b). Data triangulation through interviews, discussions and focus groups was necessary as unfree workers did not always perceive themselves to be in forced labour. The ILO catalogue's indicators are categorised as: unfree recruitment, work and life under duress, and impossibility of leaving the employer. In each category are strong and medium indicators for involuntariness and menace of penalty. One example of a strong indicator for menace of penalty in the category "unfree recruitment of adults" is the withholding of assets or cash; an example of a medium indicator is the exclusion from future employment (Verité, 2011a).

Effective tools and indicator systems for detecting slavery in a supply chain must therefore make use of a combination of monitoring of risk indicators, triangulation of various data sources, and inspections (see Table 2). However, the availability of data, inspection capacity and access to local knowledge will vary between regions and empirical case work is required to provide solid information on how to allocate tools and indicators to various context-specific supply scenarios.

Table 2: Characteristics of tools and indicator systems for detecting slavery in supply chains

\begin{tabular}{ll}
\hline Main characteristics & Description \\
\hline Risk monitoring & $\begin{array}{l}\text { Indicators are continuously monitored across geographical } \\
\text { areas thus setting up a risk-radar for slavery. }\end{array}$ \\
$\begin{array}{l}\text { Triangulation of indicators } \\
\text { and data sources }\end{array}$ & $\begin{array}{l}\text { Indicators and data sources are triangulated in order to } \\
\text { substantiate suspicion of slavery in specific geographical } \\
\text { areas and industry sectors. }\end{array}$ \\
Targeted investigation & $\begin{array}{l}\text { Targeted investigations are carried out by focal companies, } \\
\text { independent auditing bodies or governmental agencies if the } \\
\text { use of slave labour is reasonably suspected. }\end{array}$ \\
\hline
\end{tabular}




\section{(4) Potential company responses to the detection of slave labour in the supply chain}

If slavery is detected in a supply chain, the most straightforward response by companies is to radically withdraw their sourcing activities from the entire region or country. Toor (2001, p.201) draws a similar conclusion when investigating multi-national-companies' responses to the detection of child labour at a supplier level: "In this age of fly-by-night capital, it is usually easier for multinational corporations to pack up and leave undesirable areas for greener pastures". Even if slave labour tends to pull down the local and regional wage level and slaves do not fuel local consumption because they lack purchasing power (Datta and Bales, 2013), a general withdrawal would substantially worsen the socio-economic situation in the region. Furthermore, a withdrawal would not necessarily solve the specific problem of slave labour in the community and/or at an individual level since competitors (for example those serving markets with less public and consumer awareness of human rights issues) may easily take over the supply produced by slave labour. This consideration underlines the responsibility of focal companies toward the regions from which they source. It calls for company responses that go beyond risk minimisation (regarding litigation and corporate reputation) and aim for eradicating slave labour in the regions where it has been detectedtogether with the socio-economic conditions that facilitate it.

When a BBC documentary exposed the degree of slave and child labour on West African cocoa farms in 2000, both politics and business strived for adequate responses. In 2001, a voluntary agreement known as Harkin-Engel Protocol was signed that aimed at ending the worst forms of child labour in cocoa production. This agreement brought together governments, cocoa industry and producers, cocoa labourers, and civil society organizations. It was confirmed and reinforced by the Joint Declaration and accompanying Framework of Action to Support the Implementation of the Harkin-Engel Protocol in 2010 (Responsible Cocoa, 2010). The Harkin-Engel Protocol stipulated the formation of the International Cocoa Initiative (ICl) founded in 2002 as a clearing house on best practice (Responsible Cocoa, 2010) and a driver for tackling child and slave labour through a community-centred approach in Ghana and Côte d'Ivoire, working in the fields of education, health, water and sanitation, child protection and livelihood diversification. The $\mathrm{ICl}$ is funded by individual chocolate and cocoa companies and is led by a joint industry-civil society board, with the ILO in an advisory function. ICI leverages knowledge and resources in various sustainable cocoa programmes run by its member companies such as Barry Callebaut's Quality Partner Programme, Cargill's Cocoa Promise Programme, and Mondelez International's Cocoa Life Programme. It collaborates closely with the governments of cocoa-producing developing countries (ICl, 2014). While there is still a long way to go before slavery is eliminated from chocolate, the community-centred approach based on technological and social innovations, dissemination of good practice, and partnerships with a variety of actors has improved the current situation in Ghana and Côte d'Ivoire.

Determination and substantial funding from governments and/or business, an industry structure dominated by big players, and the geographic concentration of efforts are important factors in the cocoa industry's progress so far.

These factors also played a role in 2010 when Human Rights Watch (HRW, 2010) accused Philip Morris International (PMI) of sourcing from farms that used child and forced labour in Kazakhstan (Kramer, 2010). PMI responded to the allegations by commissioning Verité-a global non-profit social auditing organisation-to assess the supplying farms' adherence to 
PMl's Good Agricultural Practices (GAP) standards in Kazakhstan, including inter alia child and forced labour as well as the treatment of migrant workers (Verité, 2011b). ${ }^{4}$ Furthermore, PMl undertook various programmes to address child and forced labour, including regular and unannounced inspections as well as training for farmers and parents, and redrafted its global Agricultural Labour Policy to mandate tightened labour condition standards for suppliers (Amon et al., 2012). While the situation improved considerably among farmers supplying PMI (Phipps, 2014), the picture looks less promising at an overall country level. The United Nations Special Rapporteur on contemporary forms of slavery acknowledges significant progress in the fight against child and slave labour on tobacco farms in Kazakhstan but urges the government and companies to undertake further necessary steps towards establishing effective enforcement and monitoring mechanisms (UNOG, 2014).

Such approaches to the reduction of slavery in the supply chain can be categorised by their main lever of action. Multi-stakeholder initiatives-such as the $\mathrm{ICl}$-address numerous stakeholders: buyers and suppliers of the product, government and local enforcement authorities, labour unions and others. Its key idea is to get as many stakeholders as possible to buy into the reduction of slavery in order to gain legitimacy and effectiveness (Schouten and Glasbergen, 2011). Community-centred approaches aim to change the local institutional setting so as to immunize regions against slavery (Muthuri et al., 2012). Besides strategies for enhancing livelihood, this can for example involve education and the establishment of labour rights and civil rights groups to stimulate long-term cultural and economic changes. The third approach, as with the example of PMI, focusses on working with the supply base and on developing suppliers (Hall and Matos, 2010; Gimenez and Tachizawa, 2012); enabling them to perform productively in their business without the use of slave labour. Supplier development usually involves technology and knowledge transfer to suppliers, high levels of collaboration, and awareness-raising regarding product quality including the protection of human and labour rights during the production process.

All three approaches may contribute towards mitigating the use of slave-labour, but they address the problem through different routes and use different levers (see Table 3 ). While being highly dependent on the local circumstances and the industry of the supply chain where slavery was found, in practice all three approaches are often found to work together.

Table 3: Remediating responses to detection of slavery in the supply chain

\begin{tabular}{lll}
\hline Approach & Main features & Role of focal companies \\
\hline $\begin{array}{l}\text { Multi- } \\
\text { stakeholder } \\
\text { initiative (MSI) }\end{array}$ & $\begin{array}{l}\text { Brings together a variety of stakeholders } \\
\text { including governments, workers, industry, } \\
\text { and civil society and international } \\
\text { organizations; facilitates sector- } \\
\text { encompassing solutions, increases } \\
\text { legitimacy, and leverages synergies. }\end{array}$ & $\begin{array}{l}\text { Developing various degrees } \\
\text { of leadership; disseminating } \\
\text { and imitating best-practice; } \\
\text { funding. }\end{array}$ \\
$\begin{array}{l}\text { Community- } \\
\begin{array}{l}\text { Focuses on families and whole communities } \\
\text { approach }\end{array}\end{array}$ & $\begin{array}{l}\text { instead of individuals thus addressing the } \\
\text { systemic causes of slave labour; may } \\
\text { address education, health, child and }\end{array}$ & $\begin{array}{l}\text { Promoting technological and } \\
\text { social innovations in } \\
\text { partnership with other } \\
\text { stakeholders; developing }\end{array}$ \\
\hline
\end{tabular}

\footnotetext{
${ }^{4}$ For more work in the non-profit sector on awareness-raising and intervention around supply chains, see http://madeinafreeworld.com/business and http://slaveryfootprint.org/.
} 


\begin{tabular}{lll}
\hline (CCA) & livelihood protection. & $\begin{array}{l}\text { culturally-sensitized learning } \\
\text { attitude; funding. }\end{array}$ \\
$\begin{array}{lll}\text { Supplier } \\
\text { development } \\
\text { and capacity- } \\
\text { building }\end{array}$ & $\begin{array}{l}\text { Trains suppliers and builds capacity among } \\
\text { workers, raises awareness of the problem, } \\
\text { decreases vulnerability to slave labour and } \\
\text { other exploitative practices. }\end{array}$ & $\begin{array}{l}\text { Supplier development } \\
\text { programmes; } \\
\text { transfer; capacity-building in } \\
\text { partnership with NGOs } \\
\text { and/or governments; } \\
\text { funding. }\end{array}$ \\
\hline
\end{tabular}

\section{(5) Avenues for future research}

Addressing the managerial problem of slave labour in (international) supply chains implies fully understanding the problem of slavery: its appearances, its financial and socio-cultural rationale, and its stakes. While SCM research may build on insights and knowledge about slavery from a variety of disciplines (as outlined in section 2), the economic and management perspective offers particularly promising avenues for future SCM research on slavery. On a macro-economic level, slave labour in supply chains may be economically classified as an additional aspect of social external costs that need to be internalized for ensuring fair competition and functioning markets (cf. Pérez-Martínez and Vassallo-Magro, 2013). On a micro-economic level, slavery may be seen as the attempt of slave-holders to illegitimately under-price labour by taking advantage of specific conditions related to industry and the broader institutional setting, i.e., the socio-economic, cultural, regulatory, and geographic context (Crane, 2013).

Figure 1 proposes a preliminary conceptualization of the challenges that slavery poses to SCM. It focusses on developing tools and indicator systems for detecting slavery in supply chains (Table 2) and effective company responses after the detection of slavery (Table 3), which rely on appropriate capabilities to be developed at a firm level, supply chain level and business-non-business partnership level (Hahn and Gold, 2014). Detection and remediation efforts facilitated by appropriate capabilities are again embedded in a broader institutional context. 
Figure 1: Conceptualizing the challenges of slavery to supply chain management

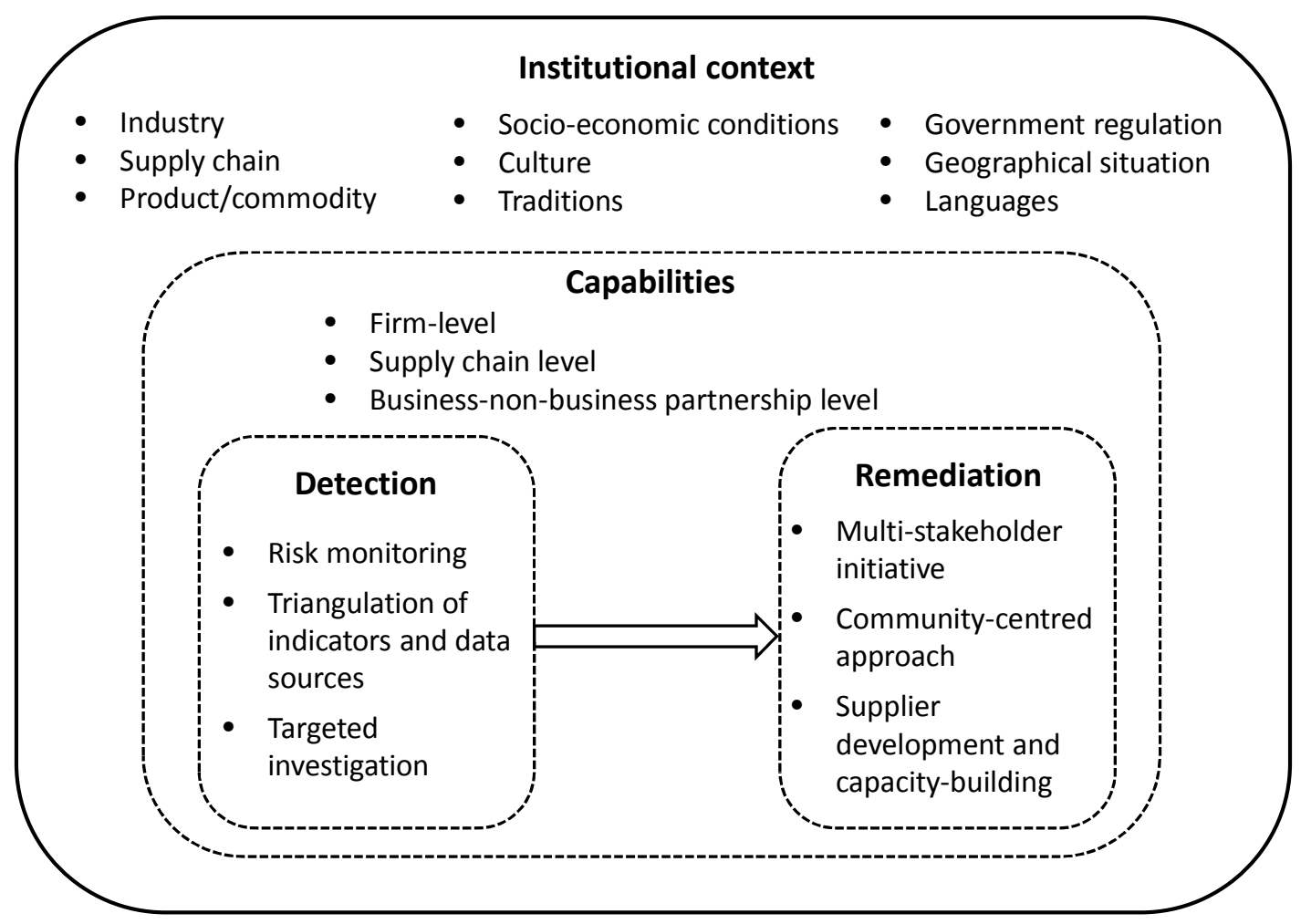

The effectiveness of the various approaches for detecting slavery and responding to the detection of slavery in supply chains (as outlined in Table 2 and Table 3) requires further empirical investigation. Conceptual or inductive empirical research may also contribute to the list of potential approaches. In terms of remediation it may specifically be asked how to cut off slave-holders' vital resources such as the in-flow of new labour, geographical isolation, or social acceptance.

Figure 1 also draws the attention of SCM researchers towards the question of which resources and capabilities need to be developed within individual companies, through collaboration along the supply chain and with further non-economic actors-such as NGOs and governmental bodies (Hahn and Gold, 2014) —for implementing the various approaches for slavery detection and remediation. These types of questions suggest the theoretical lenses of the resource-based or relational view, resource-dependency theory, or dynamic capabilities approach, which have all been used in sustainable SCM research so far (cf. the review by Sarkis et al., 2010 on green SCM).

Increasing again the level of complexity, various contingency factors referring to the broader institutional context influence how companies can build, access and exploit their resources and capabilities as well as how effectively these resources and capabilities serve the purpose of detecting and remediating slavery in supply chains. For example, according to 
our case illustrations in section 3 and section 4, an oligopolistic industry structure appears to be beneficial for effectively tackling slave labour issues in an industry sector. Research on responses from industries with predominantly small- and medium-sized enterprises characterised by fewer available resources and low buying power of single companies is therefore particularly important for the advancement of supply chain practice. Collaborative approaches that involve a multitude of companies (for example on joint auditing or community development) are hampered by the opportunistic behaviour of single firms as conceptualised by the free rider problem and game theory. As another example, supply chain managers need to adapt their actions to the characteristics of the supply chain. A long geographical distance between the point of material extraction or pre-fabrication and the point of use or consumption generally makes it harder for businesses to identify slavery in their supply chains and requires local capacity, for example the involvement of local NGOs and governmental bodies (Hahn and Gold, 2014). High degrees of fragmentation and disintegration in supply chains make distant parts of the supply chain less visible and therefore make it easy to hide slavery (Bitran et al., 2007). In contrast to some other sustainability aspects, slavery is not measurable ex-post because commodity-type products made from slave labour cannot be identified once they reach the supply chain's next tier. This consideration also changes possible remediating action on the market side by focal companies as a product recall may not only be harder to justify than for potentially consumer harming products, it may even be impossible to effectively execute.

These types of questions may be framed by contingency theory (Sousa and Voss, 2008), and institutional theory (Sarkis et al., 2010). Concerning the former, knowledge from other disciplines as outlined in Table 1 may help to achieve a deeper understanding of contingency factors such as culture, geography, legislation and regulation. The latter may investigate why and how slave-holders can continuously resist mimetic, normative and coercive isomorphic pressures towards more legitimate forms of business (DiMaggio and Powell, 1983). Thus, supply chain managers may see more clearly which actions to take (also in collaboration with other non-economic actors) in order to weaken this resistance, with the ultimate aim of making their supply chains slavery-free.

\section{References}

Allain, J. (2009), "The Definition of Slavery in International Law", Howard Law Journal, Vol. 52 No. 2, pp. 239-275.

Amon, J.J., Buchanan, J., Cohen, J. and Kippenberg J. (2012), "Child Labor and Environmental Health: Government Obligations and Human Rights", International Journal of Pediatrics, Article ID 938306, pp. 1-8.

Andersen, M. and Skjoett-Larsen, T. (2009), "Corporate social responsibility in global supply chains", Supply Chain Management: An International Journal, Vol. 14 No. 2, pp. 7586.

Bafilemba, F., Mueller, T. and Lezhnev, S. (2014), The Impact of Dodd-Frank and Conflict Minerals Reforms on Eastern Congo's Conflict, The Enough Project, June 2014.

Bai, C. and Sarkis, J. (2014), "Determining and applying sustainable supplier key performance indicators", Supply Chain Management: An International Journal, Vol. 19 No. 3, pp. 275-291. 
Bales, K. (2016), Blood and Earth: Modern Slavery, Ecocide, and the Secret to Saving the World, Random House, New York.

Bales, K. and Trodd, Z. (2013), Addressing contemporary forms of slavery in EU external policy: Briefing Paper for the European Parliament's Subcommittee on Human Rights, EXPO/B/DROI/2012/20, December 2013, available at:

http://bookshop.europa.eu/de/addressing-contemporary-forms-of-slavery-in-euexternal-policy-pbBB0113823/ (accessed 30 January 2015)

Bales, K., Trodd, Z. and Williamson, A.K. (2009), Modern Slavery: The secret world of 27 million people, Oneworld, Oxford.

Barrientos, S., Kothari, U. and Phillips, N. (2013), "Dynamics of Unfree Labour in the Contemporary Global Economy", Journal of Development Studies, Vol. 49 No. 8, pp. 1037-1041.

Bellagio-Harvard Guidelines (2012), Bellagio-Harvard Guidelines on the Legal Parameters of Slavery, available at:

http://www.qub.ac.uk/schools/SchoolofLaw/Research/HumanRightsCentre/Resource s/Bellagio-HarvardGuidelinesontheLegalParametersofSlavery/ (accessed 3

December 2014). Also published in J. Allain (2012), The Legal Understanding of Slavery: From the Historical to the Contemporary, Oxford University Press, pp. 375380.

Bitran, G.R., Gurumurthi, S. and Sam, S.L. (2007), "The need for third-party coordination in supply chain governance", MIT Sloan Management Review, Vol. 48 No. 3, pp. 30$37+92$.

Breman, J. (2007), Labor bondage in West India: From past to present, Oxford University Press, New Delhi.

Bosco, M. and Munck, P. (2013), Conflict Minerals Compliance - Hassle or Opportunity, CSCMP Hot Topics.

CIPS-Walk Free [Chartered Institute of Purchasing and Supply-Walk Free Foundation] (2013), Modern slavery in supply chains, available at: http://www.cips.org/Documents/About\%20CIPS/Ethics/CIPS_ModernSlavery_Broch_ WEB.pdf (accessed 3 December 2014)

Crane, A. (2013), "Modern slavery as a management practice: Exploring the conditions and capabilities for human exploitation", Academy of Management Review, Vol. 38 No. 1, pp. 49-69.

Datta, M.N. and Bales, K. (2013), "Slavery Is Bad for Business: Analyzing the Impact of Slavery on National Economies", Brown Journal of World Affairs, Vol. 19 No. 2, pp. 205-223.

David, F., Viederman, D., Plant, R., McQuade, A., Batstone, D., Bales, K. and Costello, T. (2012), Starting a dialogue: Harnessing the power of business to eliminate modern slavery, December 2012, available at: http://www.walkfreefoundation.org/wpcontent/uploads/2014/02/harnessing_the_power_of_business_to_eliminate_modern_ slavery.pdf (accessed 3 December 2014)

DiMaggio, P.J. and Powell, W.W. (1983), "The iron cage revisited: institutional isomorphism and collective rationality in organizational fields", American Sociological Review, Vol. 48 No. 2, pp.147-160.

Gimenez, C. and Tachizawa, E.M. (2012), "Extending sustainability to suppliers: a systematic literature review", Supply Chain Management: An International Journal, Vol. 17 No. 5, pp. 531-543. 
GRI [Global Reporting Initiative] (2013), G4 Sustainability Reporting Guidelines: Reporting Principles and Standard Disclosures, available at: https://www.globalreporting.org/resourcelibrary/GRIG4-Part1-Reporting-Principlesand-Standard-Disclosures.pdf (accessed 9 September 2014)

Grimm, J.H., Hofstetter, J.S. and Sarkis, J. (2014), "Critical factors for sub-supplier management: A sustainable food supply chains perspective", International Journal of Production Economics, Vol. 152, pp. 159-173.

Gunasekaran, A., Patel, C. and McGaughey, R.E. (2004), "A framework for Supply Chain Performance Measurement", International Journal of Production Economics, Vol. 87 No. 8, pp. 333-347.

Hahn, R. and Gold, S. (2014), "Resources and governance in "base of the pyramid"partnerships: Assessing collaborations between businesses and non-business actors", Journal of Business Research, Vol. 67 No.7, pp. 1321-1333.

Hall, J. and Matos, S. (2012), "Incorporating impoverished communities in sustainable supply chains", International Journal of Physical Distribution and Logistics Management, Vol. 40 No. 1-2, pp. 124-147.

Hodal, K., Kelly, C., and Lawrence, F. (2014), "Revealed: Asian slave labour producing prawns for supermarkets in US, UK". The Guardian, Tuesday 10 June 2014.

HRW [Human Rights Watch] (2010), Hellish Work" - Exploitation of Migrant Tobacco Workers in Kazakhstan, July 2010, available at: http://www.hrw.org/sites/default/files/reports/kazakhstan0710webwcover_1.pdf (accessed 8 January 2015)

ICI [International Cocoa Initiative] (2014), The International Cocoa Initiative - Annual Report 2013, available at: http://www.cocoainitiative.org/en/documents-manager/english/56annual-report-2013/file (accessed 8 January 2015)

ILO [International Labour Organisation] (2012a), Global Estimate of Forced Labour, available at: http://www.ilo.org/washington/areas/elimination-of-forcedlabor/WCMS_182004/lang--en/index.htm (accessed 28 January 2015)

ILO [International Labour Organisation] (2012b), Hard to see, harder to count - Survey guidelines to estimate forced labour of adults and children, available at: http://www.ilo.org/beirut/publications/WCMS_182096/lang--en/index.htm (accessed 9 January 2015)

Kramer, A.E. (2010), "Philip Morris Is Said to Benefit from Child Labor", The New York Times, 14 July 2010, p. B2.

Lebaron, G. (2013), "Unfree Labour beyond Binaries: Insecurity, social hierarchy and labour market restructuring", International Feminist Journal of Politics, article in press, doi: 10.1080/14616742.2013.813160.

Lund-Thomsen, P. (2008), "The global sourcing and codes of conduct debate: Five myths and five recommendations", Development and Change, Vol. 39 No. 6, pp. 10051018.

Lund-Thomsen, P. and Lindgreen, A. (2014), "Corporate Social Responsibility in Global Value Chains: Where Are We Now and Where Are We Going?", Journal of Business Ethics, Vol. 123 No. 1, pp. 11-22.

Magnan, G.M., Fawcett, S.E., Alcantar, T.N. and Henshaw, K. (2011), "On supply chains and reputation risk: Tracking changes in supplier codes of conduct", International Journal of Procurement Management, Vol. 4 No. 6, pp. 567-588.

McGrath, S. (2013), "Fuelling global production networks with slave labour?: Migrant sugar cane workers in the Brazilian ethanol GPN", Geoforum, Vol. 44, pp. 32-43. 
Modern Slavery Bill (2015), HL Bill 69, available at:

www.publications.parliament.uk/pa/bills/lbill/2014-2015/0069/15069.pdf (accessed 31 January 2015)

Müller, M., Gomes dos Santos, V. and Seuring, S. (2009), "The contribution of environmental and social standards towards ensuring legitimacy in supply chain governance", Journal of Business Ethics, Vol. 89 No. 4, pp. 509-523.

Muthuri, J.N., Moon, J. and Idemudia, U. (2012), "Corporate Innovation and Sustainable Community Development in Developing Countries", Business and Society, Vol. 51 No. 3, pp. 355-381.

National Pact for the Eradication of Slave Labour (2005), available at: http://www.ilo.org/wcmsp5/groups/public/---dgreports/---ilowashington/documents/genericdocument/wcms_189835.pdf (accessed 30 January 2015)

Pagell, M. and Wu, Z. (2009), "Building a more complete theory of sustainable supply chain management using case studies of 10 exemplars", Journal of Supply Chain Management, Vol. 45 No. 2, pp. 37-56.

Pagell, M., Wu, Z. and Wasserman, M.E. (2010), "Thinking differently about purchasing portfolios: An assessment of sustainable sourcing", Journal of Supply Chain Management, Vol. 46 No. 1, pp. 57-73.

Pérez-Martínez, P.J. and Vassallo-Magro, J.M. (2013), "Changes in the external costs of freight surface transport In Spain", Research in Transportation Economics, Vol. 42 No.1, pp. 61-76.

Phipps, S. (2014), "Supply Chain Briefing Part 3: Systemic change", Ethical Corporation, 10 September 2014.

Pollitt, M. (2014), "Freeing the slaves from our supply chains", Human Resource Management International Digest, Vol. 22 No. 7, pp. 1-4.

Responsible Cocoa (2010), The Harkin-Engel Protocol, available at: http://responsiblecocoa.com/about-us/the-harkin-engel-protocol/ (accessed 8 January 2015)

Rush, V. (2007), Ethanol Slavery Found on Brazil Plantation. EIR, July 20, available at: http://www.larouchepub.com/eiw/public/2007/eirv34n28-20070720/32_728.pdf (accessed 13 January 2015)

Sarkis, J., Zhu, Q. and Lai, K.-H. (2011), "An organizational theoretic review of green supply chain management literature", International Journal of Production Economics, Vol. 130 No. 1 , pp. 1-15.

Schouten, G. and Glasbergen, P. (2011), "Creating legitimacy in global private governance: The case of the Roundtable on Sustainable Palm Oil", Ecological Economics, Vol. 70 No. 11, pp. 1891-1899.

Seuring, S. and Müller, M. (2008), "From a literature review to a conceptual framework for sustainable supply chain management", Journal of Cleaner Production, Vol. 16 No. 15, pp. 1699-1710.

Sousa, R. and Voss, C.A. (2008), "Contingency research in operations management practices”, Journal of Operations Management, Vol. 26 No. 6, pp. 697-713.

Stiller, S. and Gold, S. (2014), "Socially sustainable supply chain management practices in the Indian seed sector - a case study", Supply Chain Forum: An International Journal, Vol. 5 No. 1, pp. 52-67. 
Tachizawa, E.M. and Wong, C.Y. (2014), "Towards a theory of multi-tier sustainable supply chains: a systematic literature review", Supply Chain Management: An International Journal, Vol. 19 No. 5/6, pp. 643-663.

Toor, S. (2001), "Child labor in Pakistan: Coming of age in the new world order", Annals of the American Academy of Political and Social Science, Vol. 575, pp. 194-224.

U.S. Department of Labor (2014a), List of Goods Produced by Child Labor or Forced Labor, available at: www.dol.gov/ilab/reports/child-labor/list-of-goods (accessed 30 January 2015)

U.S. Department of Labor (2014b), List of Products Produced by Forced or Indentured Child Labor, available at: www.dol.gov/ilab/reports/child-labor/list-of-products (accessed 30 January 2015)

United Nations (2011), Guiding Principles on Business and Human Rights, available at: http://www.ohchr.org/Documents/Publications/GuidingPrinciplesBusinessHR_EN.pdf (accessed 30 January 2015)

UNODC [United Nations Office on Drugs and Crime] (2012), Global Report on Trafficking in Persons, Vienna.

UNOG [United Nations Office in Geneva] (2014), Kazakhstan urged to step up fight against slavery, Geneva.

Varsei, M., Soosay, C., Fahimnia, B. and Sarkis, J. (2014), "Framing sustainability performance of supply chains with multidimensional indicators", Supply Chain Management: An International Journal, Vol. 19 No. 3, pp. 242-257.

Verité (2011a), Research on indicators of forced labor in the Supply Chain of Fish in Indonesia: Platform (Jermal) Fishing, Small-Boat Anchovy Fishing, and Blast Fishing, available at:

http://www.verite.org/sites/default/files/images/Research\%20on\%20Indicators\%20of \%20Forced\%20Labor\%20in\%20the\%20Indonesian\%20Fishing\%20Sector_9.16.pdf (accessed 9 January 2015)

Verité (2011b), Farm Level Assessment of Adherence to PMI GAP Standards in Kazakhstan, April 2011, available at:

http://www.verite.org/sites/default/files/images/Verite_Report_for_PMI_on_Kazakhsta n-2_May_2011.pdf (accessed 8 January 2015)

Vermeulen, W.J.V. and Kok, M.T.J. (2012), "Government interventions in sustainable supply chain governance: Experience in Dutch front-running cases", Ecological Economics, Vol. 83, pp. 183-196.

Walk Free Foundation (2014), Global Slavery Index 2014.

Wieland, A. and Handfield, R. (2013), "The socially responsible supply chain: An imperative for global corporations", Supply Chain Management Review, Vol. 17 No. 5, pp. $22-$ 29.

Wolf, J. (2014), "The Relationship between Sustainable Supply Chain Management, Stakeholder Pressure and Corporate Sustainability Performance", Journal of Business Ethics, Vol. 119 No. 3, pp. 317-328. 